\title{
Anthropometric Measurements of Athletes Performed by Teachers of the Faculty for Sport and Physical Education, University of Montenegro in 2017
}

\author{
Svetlana Mandic ${ }^{1}$ \\ 'University of Montenegro, Faculty for Sport and Physical Education, Niksic, Montenegro
}

\begin{abstract}
The Center for Diagnostics in Sport, which is an integral part of the Faculty for Sport and Physical Education University of Montenegro, was established in 2017. It was accredited by the Ministry of Science and systematized by the University of Montenegro. The main function of the Center is to conduct research that will contribute to the improvement of scientific work in the field of sports sciences, as well as scientific branches and disciplines that are directly or indirectly related to sport and sports science. During the first year of its work, the Center justified its purpose and from May 20 to October 27 teachers of the Faculty for Sport and Physical Education, carried out 40 anthropometric measurements having tested individuals, clubs and national teams of different age groups from the country and abroad. In this paper, we classified the performed tests according to the countries where the athletes come from, as well as according to sports; separately for national teams, clubs and individuals. It was determined that the majority of the tested athletes were from Montenegro; even 22 national teams passed the tests. It was also determined from which sports there was the largest number of tested participants, as well as who the tested individuals were. Further research, which will include anthropometric measurements from 2018, can be based on this research. In addition, this research is significant because it gives an overview of all tests performed during the first year of work of the Center for Diagnostics in Sport.
\end{abstract}

Keywords: The Center for Diagnostics, Sport, Anthropometric Measurements, Athletes

\section{Uvod}

Fakultet za sport i fizičko vaspitanje je jedna od organizacionih jedinica Univerziteta Crne Gore koja se značajno ističe kada je primijenjeni i razvojni naučno-istraživački rad u pitanju, svjesni činjenice da uspješno primijenjeni naučni rezultati u sportu značajno doprinose podizanju kvaliteta rada i postizanju dobrih sportskih rezultata. Zbog toga se na Fakultetu nastoji uspostaviti respektabilna naučna baza podataka koja će pomoći sportistima i sportskim stručnjacima da rezultati budu što bolji, a naučnim radnicima služiti kao osnova za brojna istraživanja.

Antropometrija je važan faktor u selekciji sportista (G. Moreno, L. Moreno, \& Jaramillo, 2011), a od poznavanja strukture pojedinih antropoloških sposobnosti i karakteristika, kao i njihovog razvoja, zavisi i kvalitetno upravljanje procesom sportskog treninga (Bjelica, 2005; Bjelica, 2013). Informacije o kvalitetu izvršenja trenažnih zadataka se u velikoj mjeri ogledaju kroz antropometrijske karakteristike (Ramos-Campo et al., 2014; Masanovic \& Vukasevic, 2009), koje opet, s druge strane, zajedno sa tjelesnom kompozicijom i konstitucijom sportista,

Correspondence:

Montenegro University of Montenegro,

Gport Faculty for Sport and Physical Education, Narodne omladine bb, 81400 Niksic, Montenegro E-mail: bsz@t-com.me 
imaju za cilj prilagođavanje sportskog treninga individualnim sposobnostima i mogućnost prognoziranja krajnjih dometa (Mašanović, 2009).

Sportski stručnjaci spoznali su da je dijagnostika u sportu postala neophodna, dok naučnici iz sfere sportskih nauka nastoje da relevantnim podacima i istraživanjima pomognu sportistima i sportskim radnicima da stignu do vrhunskih rezultata. Zajedničko djelovanje sporta i nauke rezultiralo je antropometrijskim mjerenjima koja su realizovana u Centru za dijagnostiku u sportu, formiranom 2017. godine, koji je sastavni dio Fakulteta za sport i fizičko vaspitanje.

Centar je za samo pola godine (od 20. maja do 27. oktobra 2017. godine) realizovao čak 40 mjerenja, što je više od šest mjerenja mjesečno, i time najavio kvalitetan i produktivan rad u godinama koje slijede, ali i stvaranje impozantne naučne baze podataka koja će pomoći sportistima i sportskim stručnjacima da rezultati budu što bolji, a nastavnicima sa Fakulteta za sport i fizičko vaspitanje poslužiće kao osnova za brojna istraživanja, kao i za naučne radove (Faculty for Sport and Physical Education, 2020).

Osnovni cilj ovog istraživanja je da se prezentovanjem mjerenja koja su obavljena tokom 2017. godine javnost upozna sa postojanjem Centra za dijagnostiku, njegovim radom i značajem, kako za nauku, tako i za sportiste. Cilj nam je takođe da javnosti prikažemo ko su sportisti, sportski klubovi i reprezentacije koje su te godine testirane, iz kojih zemalja dolaze i kojim sportovima se bave, kao i koji su to naučni radovi nastali zahvaljujući rezultatima dobijenim tokom obavljenih mjerenja i daljim istraživanjem.

\section{Metod}

Uzorak ovog istraživanja čini 40 antropometrijskih mjerenja koje su nastavnici Fakulteta za sport i fizičko vaspitanje tokom 2017. godine sproveli, a testirani su kako pojedinci, tako i klubovi i reprezentativne selekcije iz zemlje i inostranstva i to različite životne dobi, ali i različitih sportskih disciplina. Testiranja su obavljena kako u Centru za dijagnostiku, tako i u klubovima, na sportskim bazenima, i to u Crnoj Gori i u regionu.

Kompletna antropometrijska mjerenja realizovana su uz poštovanje osnovnih pravila i principa, vezanih za izbor standardizovanih mjernih instrumenata i tehnike mjerenja, prema uputstvima Internacionalnog biološkog programa.

Antropometrijska mjerenja realizovana su antropometrom, kaliperom i centimetarskom trakom, a izmjereno je sedam antropometrijskih mjera: visina i težina tijela, obim struka i kožni nabori tricepsa, bicepsa, leđa i trbuha. Za procjenu sastava tijela korišćena je inovativna tanita vaga, model BC-418MA, koja radi na principu bioelektrične impedanse. Zahvaljujući atletskom modu koji posjeduje, omogućava sportistima detaljno praćenje tjelesne težine, zdravstvenog stanja i kondicije, sa svim relevantnim parametrima. Dobijeni su podaci za četiri varijable: indeks tjelesne mase, procenat masti (kako u strukturi tijela, tako i u ekstremitetima, kao i vrijednosti visceralnih masti), mišićna i koštana masa.

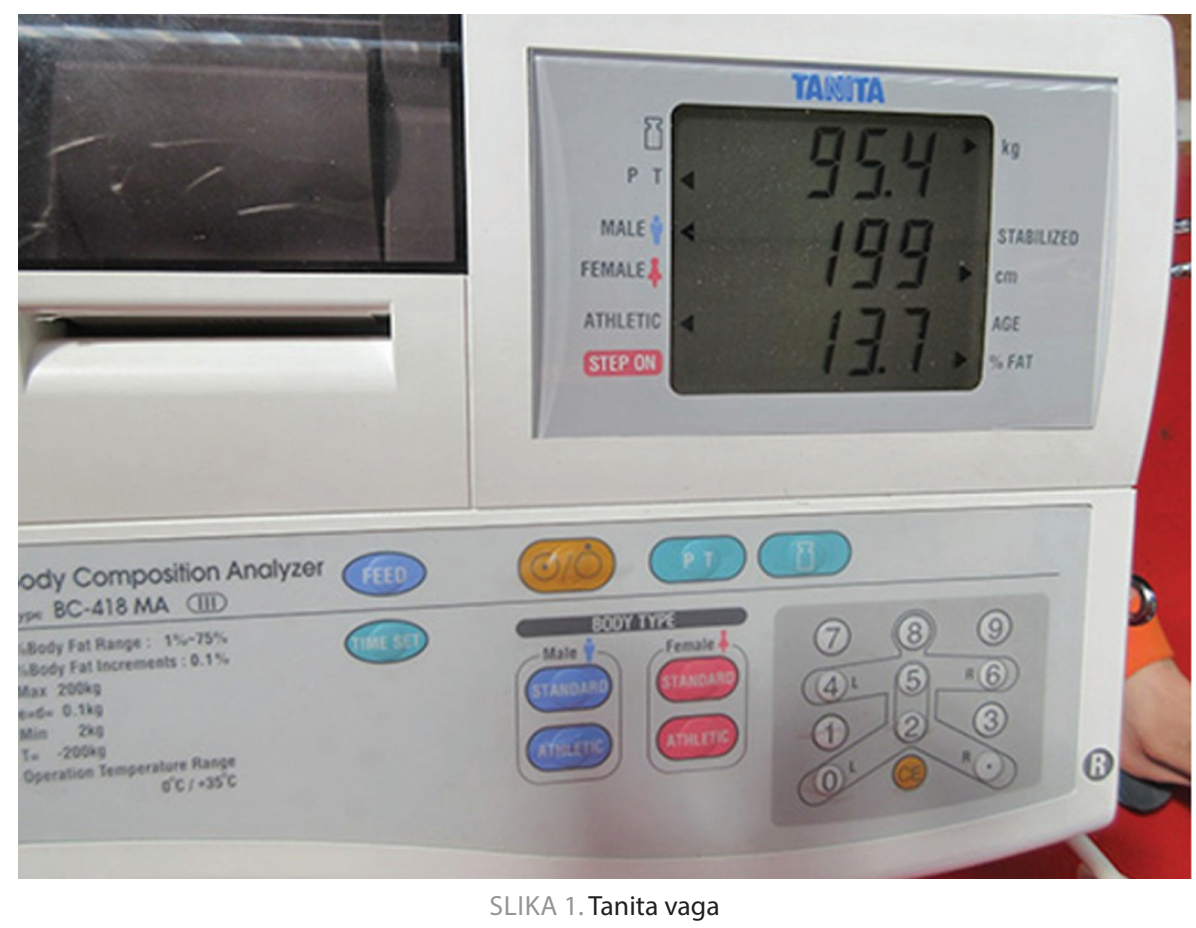

Podaci dobijeni ovim istraživanjem, a odnose se na to koje reprezentacije, klubovi i pojedinci, i iz kojih sportskih disciplina, su prošli antropometrijska mjerenja, obrađeni su deskriptivnom i komparativnom statističkom procedurom.

\section{Rezultati}

Mjerenjima su bili obuhvaćeni sportisti iz 12 zemalja: Crne Gore, Srbije, Hrvatske, Bosne i Hercegovine, Kosova, Francuske, Rusije, Grčke, Australije, Izraela, Mađarske i Španije. Ukupno su testirane 22 reprezentativne selekcije, deset klubova i osam pojedinaca.

U Tabeli 1 prikazano je iz kojih zemalja su sportisti koji su testirani tokom 2017. godine, kao i iz kojih država su testirane repre- zentativne selekcije, klubovi i pojedinci.

Testirani sportisti bili su iz različitih sportova: fudbala, košarke, rukometa, odbojke, vaterpola, džudoa, karatea, atletike i boksa (Tabela 2). Najviše reprezentacija testirano je iz vaterpola, devet, i košarke, osam. Zatim slijede tri reprezentacije iz rukometa i po jedna iz odbojke i boksa. Kada su sportski klubovi u pitanju, tokom 2017. godine testirano je osam fudbalskih klubova (po tri iz Crne Gore i Kosova i dva iz $\mathrm{BiH}$ ) i dva iz rukometa (po jedan iz Crne Gore i BiH). Svi testirani pojedinci, njih osmoro, bili su iz Crne Gore: džudisti, Danilo Pantić, Nikola Gardašević i Jovana Peković; atletičarke, Marija Vuković, Slađana Perunović i Kristina Rakočević; i karatisti, Marina Raković i Mario Hodžić. 
Tabela 1. Mjerenja koja su obavljena u toku 2017. godine

\begin{tabular}{lccc}
\hline Države: & Reprezentacije: & Klubovi: & Pojedinci: \\
\hline Crna Gora & 12 & 4 & 8 \\
Bosna i Hercegovina & - & 3 & - \\
Kosovo & - & 3 & - \\
Rusija & 2 & - & - \\
Srbija & 1 & - & - \\
Hrvatska & 1 & - & - \\
Francuska & 1 & - & - \\
Grčka & 1 & - & - \\
Australija & 1 & - & - \\
Izrael & 1 & - & - \\
Mađarska & 1 & - & - \\
Španija & 1 & - & - \\
Ukupno & 22 & 10 & 8 \\
\hline
\end{tabular}

Tabela 2. Mjerenjem su bili obuhvaćeni sportisti iz devet sportova

\begin{tabular}{lccc}
\hline Sport: & Reprezentacija: & Klub: & Pojedinci: \\
\hline Fudbal & - & 8 & \\
Košarka & 8 & - & - \\
Rukomet & 3 & 2 & - \\
Odbojka & 1 & - & - \\
Vaterpolo & 9 & - & - \\
Džudo & - & - & 3 \\
Atletika & - & - & 3 \\
Karate & - & - & 2 \\
Boks & 1 & - & - \\
Ukupno & 22 & 10 & 8 \\
\hline
\end{tabular}

Prvo testiranje u 2017. godini realizovano je 20. maja, kada su nastavnici i saradnici Fakulteta za sport i fizičko vaspitanje Univerziteta Crne Gore, na bazenu Sportsko-rekreativnog centra u Nikšiću, izvršili antropometrijsko mjerenje seniorske vaterpolo reprezentacije Crne Gore.

Zatim su uslijedila mjerenja fudbalera FK Mladost iz Podgo-

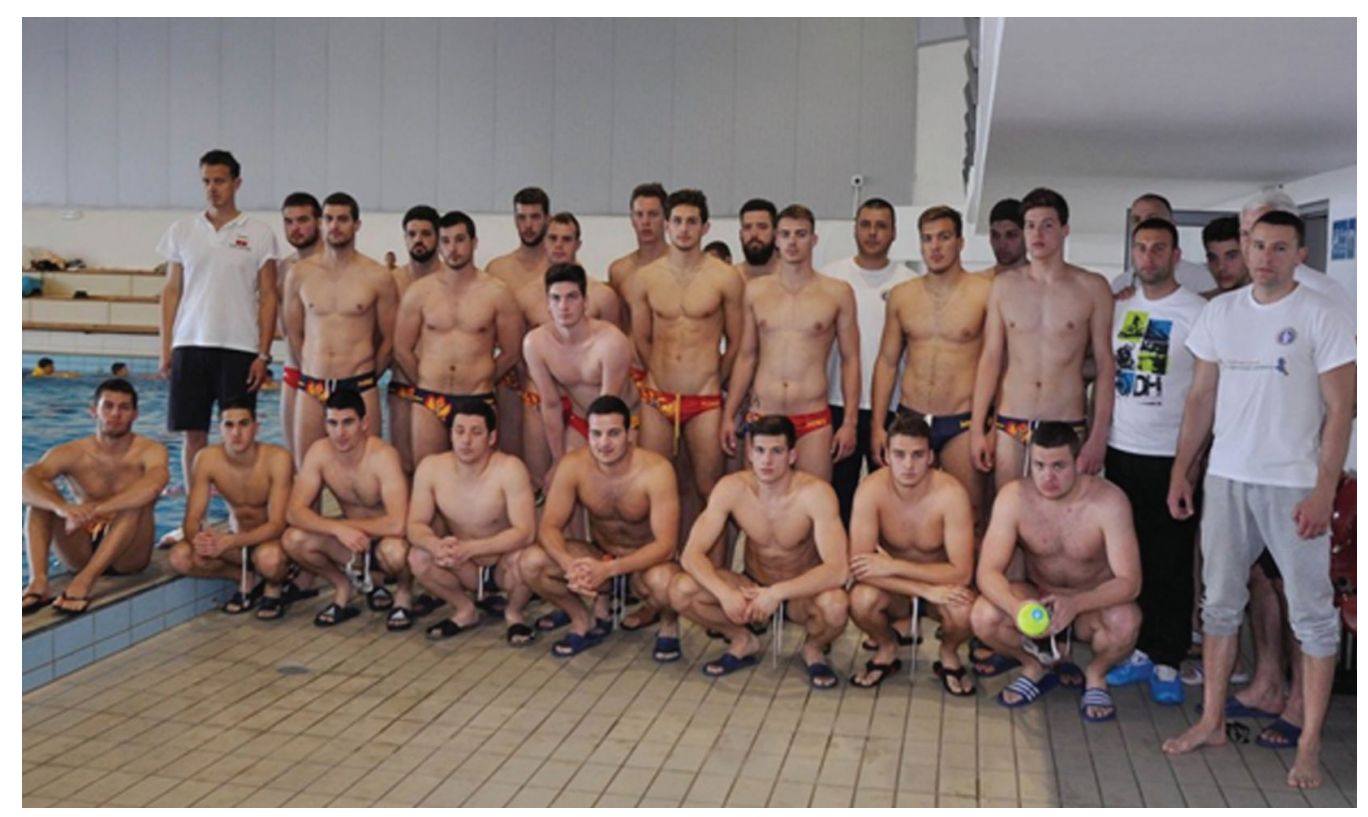

SLIKA 2. Seniorska vaterpolo reprezentacija Crne Gore i nastavnici Fakulteta koji su obavili mjerenje 
rice, koji su u sezoni 2016/17. osvojili isti broj bodova kao i prvak Budućnost, ali su zbog lošijeg međusobnog skora morali da se zadovolje drugim mjestom, ženske seniorske i kadetske rukometne reprezentacije Crne Gore, mlade košarkaške reprezentacije Crne Gore, fudbalera FK Sutjeska iz Nikšića, osvajača Kupa Crne Gore u sezoni 2016/17, i FK Budućnost iz Podgorice, šampiona Crne
Gore u toj istoj sezoni. Antropometrijska mjerenja realizovana su i kod juniorske košarkaške reprezentacije Crne Gore.

Prva mjerenja sportista iz regiona sprovedena su kod fudbalera NK Široki Brijeg, osvajača Kupa Bosne i Hercegovine u sezoni 2016/17, i HŠK Zrinjski, koji je odbranio titulu najboljeg kluba u Premijer ligi te iste sezone.

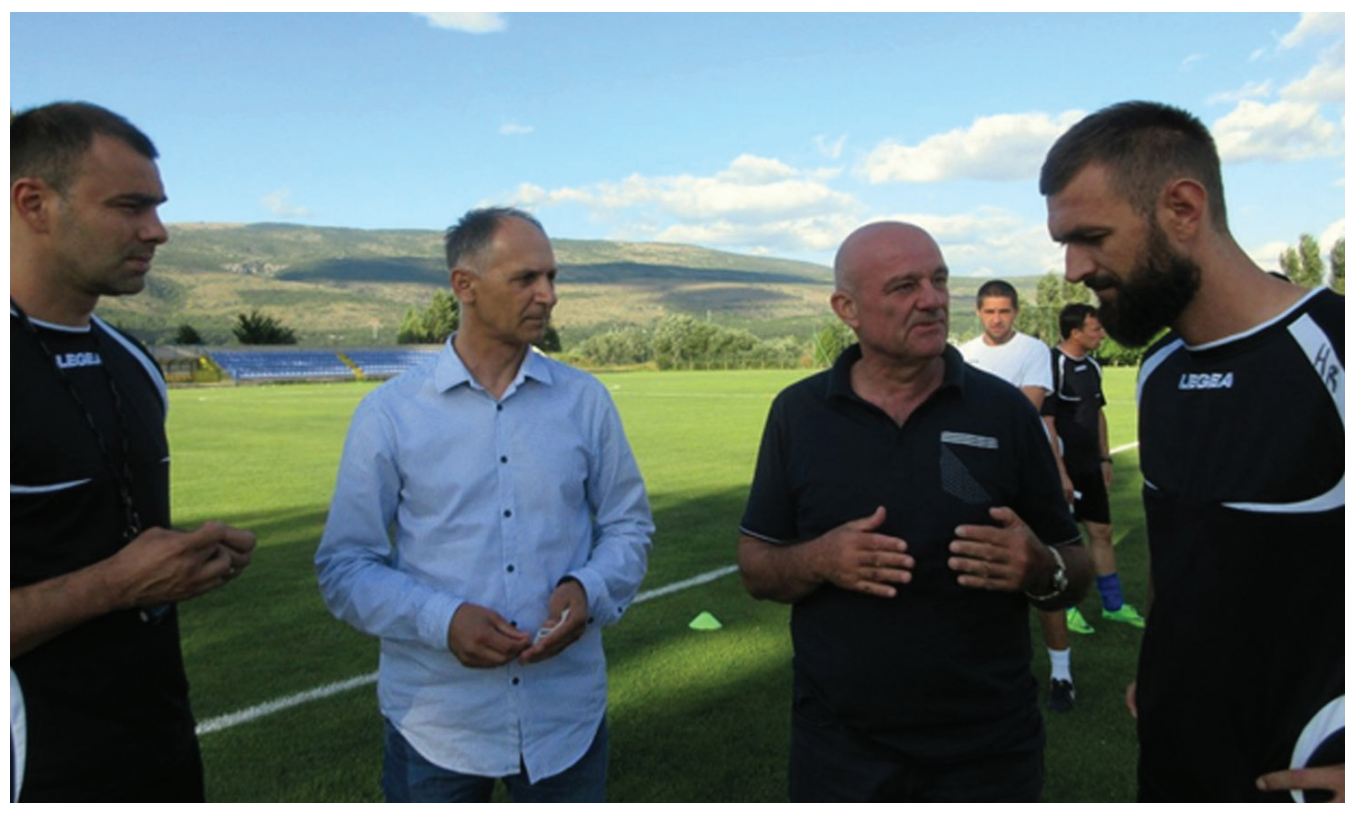

SLIKA 3. Tokom mjerenja u Širokom i Mostaru

Antropometrijska testiranja prošli su i članovi ekipe mlade bokserske reprezentacije Crne Gore, kao i stipendisti Crnogorskog olimpijskog komiteta - karatisti, Marina Raković i Mario Hodžić, i atletičarke, Marija Vuković i Slađana Perunović. Detaljno antropometrijsko mjerenje, sa svim relevantnim parametrima, kao i mjerenje funkcionalnih sposobnosti, obavljeno je i kod ženske kadetske i muške seniorske košarkaške reprezentacije Crne Gore, muških kadetskih reprezentacija Crne Gore u odbojci i košarci, muških kadetskih košarkaških reprezentacija Francuske, Izraela i Rusije, zatim muških kadetskih vaterpolo reprezentacija Grčke, Australije, Rusije, Crne Gore, Hrvatske, Srbije, Mađarske i Španije. Testirani su i fudbaleri najboljih klubova Superlige Kosova: Trepča 89 iz Kosovske Mitrovice, šampion u sezoni 2016/17. i učesnik kvalifikacija za Ligu šampiona, Priština iz Prištine, vicešampion (sezona 2016/17) i učesnik kvalifikacija za Ligu Evrope i Besa iz Peći, osvajač kupa Kosova (2016/17). Tokom septembra, testirane su rukometašice ŽRK Lavalea iz Nikšića, vicešampionke Prve lige Crne Gore za sezonu 2016/17, i stipendisti Crnogorskog olimpijskog komiteta, atletičarka Kristina Rakočević, juniorska prvakinja svijeta u atletici i najbolja mlada sportistkinja Crne Gore i to 2013, 2015 i 2016. godine, džudisti, Danilo Pantić i Nikola Gardašević, koji su prije toga na Balkanskom seniorskom prvenstvu osvojili zlato, i Jovana Peković, najuspješnija crnogorska džudistkinja

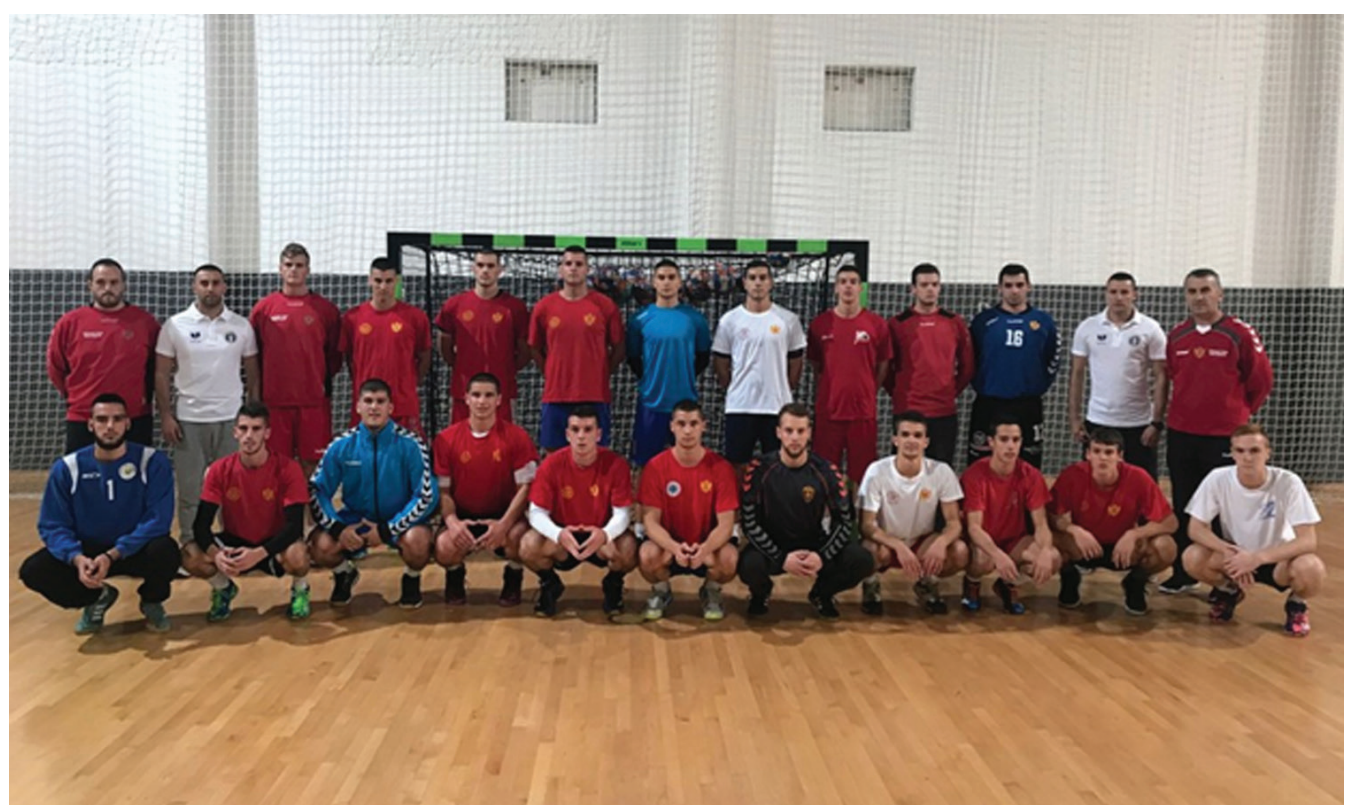

SLIKA 4. Juniorska muška rukometna reprezentacija Crne Gore i nastavnici Fakulteta koji su obavili mjerenje 
u 2016. godini, koja je godinu ranije osvojila bronzanu medalju na Svjetskom kadetskom prvenstvu. Još jedna ekipa iz Bosne i Hercegovine je prošla antropometrijsko testiranje - riječ je o ženskom rukometnom klubu Grude, iz istoimenog grada, šampionkama rukometne Premijer lige $\mathrm{BiH}$ u sezoni 2016/17. Posljednje mjerenje 2017. godine obavljeno je 27. oktobra na Žabljaku, gdje se, na mini pripremi, nalazila muška juniorska rukometna reprezentacija Crne Gore.

\section{Diskusija}

Razvoj savremenog sporta danas je gotovo nezamisliv bez nauke. Fakultet za sport i fizičko vaspitanje Univerziteta Crne Gore po tom pitanju prati trendove i svojim djelovanjem i teoretski i praktično pokazuje i dokazuje vezu nauke i sporta. Upravo je Centar za dijagnostiku u sportu jedan od bitnih činilaca te sveze. Kao naučno-istraživačka institucija, Centar je akreditovan od strane Ministarstva nauke i sistematizovan od strane Univerziteta Crne Gore. Njegova osnovna funkcija je istraživanje i prikupljanje rezultata koji će doprinijeti unapređenju naučnog rada iz domena sportskih nauka, kao i naučnih grana i disciplina koje su posredno ili neposredno povezane sa sportom i sportskom naukom.

Sport je odavno postao multidisciplinaran i za postizanje sportskih rezultata nije više najvažnije samo biti brz ili izdržljiv, već se dobri sportski rezultati grade na bazi više naučnih disciplina (Bjelica, 2013). Osnovna mjerna jedinica uspjeha je sportski rezultat (Havelka \& Lazarević, 1981; Bjelica i Krivokapic, 2010; Bjelica i Krivokapic, 2012). Dok sport nosi multidisciplinarno obilježje (Bjelica, 2013), sportski trening je kompleksan pedagoški proces (Bjelica, 2006). Upravo od treninga i njegovog kvaliteta zavise sportski rezultati, a u sportskim aktivnostima, tokom treninga i takmičenja, veliku važnost imaju opšte i osnovne antropološke karakteristike (Bjelica, Georgijev, \& Muratović, 2012).

Bez dijagnostike, razvoj sportista, i sporta uopšte, nemoguć je, a samim tim i postizanje najvećih sportskih uspjeha. Zbog toga Centar ima vrlo važnu ulogu u pripremi sportista i praćenju njihovog razvoja, ali i rezultata tokom treninga. Ne manji značaj Centar ima i za nauku, jer zahvaljujući rezultatima koji su dobijeni tokom obavljenih testiranja sprovedena su brojna istraživanja i objavljeni naučni radovi. Tako je, samo na osnovu rezultata dobijenih antropometrijskim mjerenjima sportista tokom 2017. godine, u časopisu Journal of Anthropology of Sport and Physical Education (JASPE), od 2018. do danas objavljeno 13 naučnih radova: Differences in the Morphological Characteristics and Body Composition of Football Players in Montenegro (Corluka \& Vasiljevic, 2018); Differences in the Morphological Characteristics and Body Composition of Football Players FC Buducnost and FC Mladost in Montenegro (Gardasevic, Bjelica, Popovic, Vasiljevic, \& Milosevic, 2018); Differences in the Morphological Characteristics and Body Composition of Football Players FC Sutjeska and FC Mladost in Montenegro (Bjelica, Gardasevic, \& Vasiljevic, 2018); Differences in the Morphological Characteristics and Body Composition of Handball Players WHC Levalea in Montenegro and WHC Grude in Bosnia and Herzegovina (Vukotić, Corluka, Vasiljević, \& Bubanja, 2018); Differences in the Morphological Characteristics and Body Composition of Football Players FC Trepca 89 and FC Prishtina in Kosovo (Gardasevic, Bjelica, Vasiljevic, Sermaxhaj, \& Arifi, 2018); Body Composition and Anthropometric Measures of Footballers, Cup Winners of Montenegro and Bosnia and Herzegovina (Bjelica, Gardasevic, Vasiljevic, \& Corluka, 2018); Differences in Anthropometric Measures of Footballers, Cup Winners of Montenegro and Kosovo (Gardasevic, Bjelica, Vasiljevic, Arifi, \& Sermaxhaj, 2019); Anthropometric Measures and Body Composition of Soccer Players of Montenegro and Kosovo (Bjelica, Gardasevic, Vasiljevic, Arifi, \& Sermaxhaj, 2019); Anthropometric Characteristics of Elite Soccer Players from Bosnia and Herzegovina and Montenegro (Corluka, Bjelica, Gardasevic, \& Vasiljevic, 2019); Differences in Body Composition of Football Players of Two Top Football Clubs (Gardasevic, Bjelica, Vasiljevic, \& Corluka, 2019); Body Composition of Soccer Players of Montenegro and Bosnia and Herzegovina (Gardasevic, Bjelica, Vasiljevic, \& Corluka, 2020); Elite Football Players of Bosnia and Herzegovinian and Kosovian Clubs and Differences in the Morphological Characteristics and Body Composition among them (Vasiljevic et al., 2020); Soccer Players of Winner of the Cup of Bosnia and Herzegovina and Kosovo Champion in Season 2016/17 and their Morphological Characteristics (Gardasevic, Bjelica, Vasiljevic, Corluka, Arifi, \& Sermaxhaj, 2020).

Imajući u vidu činjenicu da su sportisti u pojedinim sportovima često međusobno izjednačeni u mnogim relevantnim parametrima za sport povezanih karakteristika i sposobnosti (Rogulj, Nazor, Srhoj, \& Božin, 2006), rezultati koji su dobijeni tokom antropometrijskih mjerenja u Centru za dijagnostiku, a stručno sagledani od strane naučnih radnika sa Fakulteta za sport i fizičko vaspitanje, poslužiće sportistima i sportskim stručnjacima za što bolja dostignuća, a testirani sportisti, klubovi i savezi će, na osnovu njih, dobiti smjernice za dalji rad.

\section{Acknowledgments}

There are no acknowledgements.

\section{Conflict of Interest}

The authors declare that there is no conflict of interest.

Received: 5 November 2020 | Accepted: 6 December 2020 | Published: 18 January 2021

\section{References}

Bjelica, D. (2005). Sistematizacija sportskih disciplina $i$ sportski trening. Podgorica: Crnogorska sportska akademija.

Bjelica, D. (2006). Sportski trening. Podgorica: Crnogorska sportska akademija.

Bjelica, D. (2013). Teorija sportskog treninga. Podgorica: Univerzitet Crne Gore

Bjelica, D., Georgiev, G.,\& Muratović, A. (2012). Basic motor abilities of young handball players from Montenegro Sport Science, 5(1), 71-76.

Bjelica, D., i Krivokapić, D. (2010). Teorijske osnove fizičke kulture. Nikšić: Fakultet za sport i fizičko vaspitanje Univerziteta Crne Gore.

Bjelica, D., i Krivokapić D. (2012). Uticaj fizičkog vježbanja na ps homotorne funkcije starijih osoba. Zbornik radova Druge međunarodne konferencije Sportske nauke i zdravlje, Banja Luka: Panaevropski univerzitet APEIRON, 191-196.

Bjelica, D., Gardasevic, J., \& Vasiljevic, I., (2018). Differences in the Morphological Characteristics and Body Composition of Football Players FC Sutjeska and FC Mladost in Montenegro. Journal of Anthropology of Sport and Physical Education, 2(2), 31-35

Bjelica, D., Gardasevic, J., Vasiljevic, I., \& Corluka, M. (2018). Body Composition and Anthropometric Measures of Footballers, Cup Winners of Montenegro and Bosnia and Herzegovina. Journal of Anthropology of Sport and Physical Education, 2(4), 3-7

Bjelica, D., Gardasevic, J., Vasiljevic, I., Arifi, F., \& Sermaxhaj, S. (2019). Anthropometric Measures and Body Composition of Soccer Players of Montenegro and Kosovo. Journal of Anthropology of Sport and Physical Education, 3(2), 29-34

Corluka, M., \& Vasiljevic, I. (2018). Differences in the Morphological Characteristics and Body Composition of Football Players in Montenegro. Journal of Anthropology of Sport and Physical Education, 2(1), 3-7.

Corluka, M., Bjelica, D., Gardasevic, J., \& Vasiljevic, I. (2019). Anthropometric Characteristics of Elite Soccer Players from Bosnia and Herzegovina and Montenegro. Journal of Anthropology of Sport and Physical Education, 3(3), 11-15.

Faculty for Sport and Physical Education. (2020, September 10). All Anthropometric Tests Conducted at the University of Montenegro starting from 20.05.2017 - athletes, clubs and national teams from Montenegro, France, Great Britain, Serbia, Bosnia and Herzegovina, Slovenia, Croatia, Norway, Bulgaria, Ukraine, Kosovo, Albania, Estonia, Russia, Portugal, Northern Macedonia and Israel. Retrieved from University of Montenegro website: https://www.ucg.ac.me/objava/blog/1259/objava/81294

Gardasevic, J., Bjelica, D., Popovic, S., Vasiljevic, I., \& Milosevic, Z. (2018). 
Differences in the Morphological Characteristics and Body Composition of Football Players FC Buducnost and FC Mladost in Montenegro. Journal of Anthropology of Sport and Physical Education, 2(1), 51-55

Gardasevic, J., Bjelica, D., Vasiljevic, I., Sermaxhaj, S., \& Arifi, F. (2018). Differences in the Morphological Characteristics and Body Composition of Football Players FC Trepca' 89 and FC Prishtina in Kosovo. Journal of Anthropology of Sport and Physical Education, 2(3), 105-109.

Gardasevic, J., Bjelica, D., Vasiljevic, I., Arifi, F., \& Sermaxhaj, S. (2019) Differences in Anthropometric Measures of Footballers, Cup Winners of Montenegro and Kosovo. Journal of Anthropology of Sport and Physical Education, 3(21), 23-27.

Gardasevic, J., Bjelica, D., Vasiljevic, I., \& Corluka, M. (2019). Differences in Body Composition of Football Players of Two Top Football Clubs. Journal of Anthropology of Sport and Physical Education, 3(4), 15-19.

Gardasevic, J., Bjelica, D., Vasiljevic, I., \& Corluka, M. (2020). Body Composition of Soccer Players of Montenegro and Bosnia and Herzegovina. Journal of Anthropology of Sport and Physical Education, 4(1), 33-38.

Gardasevic, J., Bjelica, D., Vasiljevic, I., Corluka, M., Arifi, F., \& Sermaxhaj, S. (2020). Soccer Players of Winner of the Cup of Bosnia and Herzegovina and Kosovo Champion in Season 2016/17 and their Morphological Characteristics. Journal of Anthropology of Sport and Physical Education, 4(3), 29-31.

Havelka, N., \& Lazarevic, Lj. (1981). Sport i ličnosti. Beograd: Sportska knjiga

Masanovic, B. (2009). Razlike antropometrijskog statusa vrhunskih rukometaša inesportista. Sport Mont, 6(18-19-20), 569-575

Moreno, G.A., Moreno, L.E.A., \& Jaramillo, P.C.A. (2011). Characterization of karate athletes and college basketball: body composition and anthropometry stability. Revista Edu-Fisica., 3(8), 1-20.

Popovic, S. (2017). Local Geographical Differences in Adult Body Height in Montenegro. Montenegrin Journal of Sports Science and Medicine, 6(1), 81-87.

Ramos-Campo, D.J., Martinez-Sanchez, F., Esteban-Garcia, P., Rubio-Arias, J.A., Bores, C.A., Clemente-Suarez, V.J., \& Jimenez-Diaz, J.F. (2014). Body Composition Features in Different Playing Position of Professional Team Indoor Players: Basketball, Handball and Futsal. International Journal of Morphology, 32(4), 1316-1324.

Rogulj, N., Nazor, M., Srhoj, V., \& Božin, D. (2006). Differences between competitively effi cient and less effi cient junior handball players according to their personality traits. Kinesiology, 38(2), 158-163.

Vasiljevic, I., Bjelica, D., Gardasevic, J., Bubanja, M., Corluka, M., Arifi, F., \& Sermaxhaj, S. (2020). Elite Football Players of Bosnia and Herzegovinian and Kosovian Clubs and Differences in the Morphological Characteristics and Body Composition among them. Journal of Anthropology of Sport and Physical Education, 4(2), 9-13.

Vukotic, M., Corluka, M., Vasiljević, I., \& Bubanja, M. (2018). Differences in the Morphological Characteristics and Body Composition of Handball Players WHC Levalea in Montenegro and WHC Grude in Bosnia and Herzegovina. Journal of Anthropology of Sport and Physical Education, 2(2), 49-53. 